\title{
NOMINATIONS ]
}

The Council of the American Meteorological Society invites members of the AMS to submit nominations for the Society Awards, Lecturers, Named Symposia, Fellows, Honorary members, and nominees for elective Officers and Councilors of the Society.

Information regarding awards, including award descriptions, listings of previous recipients, and the process for submitting nominations are on the AMS website (www.ametsoc.org/ams /index.cfm/about-ams/ams -awards-honors/awards/).

\section{AWARDS COMMITTEES}

Each committee or commission listed has the responsibility to select and submit to the Council the names of individuals nominated for the Society's awards listed. In most cases, a nomination package includes the name of the individual nominated, a two-page CV, a bibliography of no more than three pages, and three supporting letters. This package should be electronically submitted before 1 May 2020 unless stated otherwise. The nominees for most awards remain on the committee's active list for three years.

\author{
ATMOSPHERIC RESEARCH AWARDS (ARA) \\ COMMITTEE \\ The Carl-Gustaf Rossby Research Medal \\ The Jule G. Charney Medal \\ The David and Lucille Atlas Remote Sensing Prize \\ (biennial) \\ The Clarence Leroy Meisinger Award \\ The Henry G. Houghton Award
}

\section{OCEANOGRAPHIC RESEARCH AWARDS (ORA) COMMITTEE}

The Henry Stommel Research Medal

The Sverdrup Gold Medal

The Nicholas P. Fofonoff Award

\section{HYDROLOGIC RESEARCH AWARDS (HRA) COMMITTEE}

The Hydrologic Sciences Medal

\section{SUOMI AWARD COMMITTEE \\ The Verner E. Suomi Technology Medal}

\section{AWARDS OVERSIGHT COMMITTEE}

The Charles Franklin Brooks Award

for Outstanding Services to the Society

The Cleveland Abbe Award for Distinguished

Service to the Atmospheric and Related

Sciences

The Joanne Simpson Mentorship Award

The Award for Outstanding Services

by a Corporation

Special Awards

\section{NOMINATING COMMITTEE}

The Committee's function is to submit to the Council the names of individuals for 1) the office of President-Elect for a term of one year starting at the close of the Annual Meeting and 2) four positions on the Council for a term of three years starting at the close of the Annual Meeting.

As per Article VI of the AMS Constitution, formal nominations by petition may be submitted to the Secretary-Treasurer by 1 July. In addition, the AMS Nominating Committee welcomes recommendations from the membership of candidates for office, which will be considered as the slate is prepared. Such recommendations will be most helpful if they are sent to the Nominating Committee nominatingcommittee@ametsoc.org by the end of December and are in the form of a 1-page letter describing the proposed candidate's background and qualifications. Questions about the nomination process should also be addressed to the Nominating Committee. 


\section{SCIENTIFIC AND TECHNOLOGICAL ACTIVITIES COMMISSION}

The Charles L. Mitchell Award

The Award for an Exceptional Specific Prediction

The Francis W. Reichelderfer Award

- LECTURERS*

The Robert E. Horton Lecturer in Hydrology

The Bernhard Haurwitz Memorial Lecturer

- PAPER

The Banner I. Miller

- NAMED SYMPOSIA

Section G, of the Guidelines for Society and Commission Awards provides the Policy on Named Conferences/Symposia/Sessions and Special Issues of AMS Journals (full policy description available at www.ametsoc.org/awards):

Recognition of scientists in the fields served by the AMS, living or deceased, in the form of a named conference or symposium or a named special issue of one of the Society's journals is an honor reserved for only the most outstanding of our colleagues. It should be awarded only to those individuals who are completing a career, or who have recently died having completed a career, of significant achievements in their field and whose contributions would make them worthy of consideration for Honorary Member of the AMS...

\section{HONORARY MEMBERS}

Article III, Section 5, of the AMS Constitution provides that Honorary Members shall be persons of acknowledged preeminence in the atmospheric or related oceanic or hydrologic sciences, either through their own contributions to the sciences or their application or through furtherance of the advance of those sciences in some other way. They shall be exempt from all dues and assessments. The nominees for Honorary member remain on an active list for three years.

A form and list of Honorary Members is available at www.ametsoc.org/ams/index.cfm/aboutams/ams-awards-honors/honorary-members/.

\section{FELLOWS COMMITTEE}

The Committee's function is to submit to the Council the names of individuals for election to Fellow.

Article III, Section 6, of the AMS Constitution provides that those eligible for election to Fellow shall have made outstanding contributions to the atmospheric or related oceanic or hydrologic sciences or their applications during a substantial period of years. The nominees for Fellow must be a member of the Society and remain on the committee's active list for three years.

A nomination letter and three supporting letters should be electronically submitted before 1 May 2020. A list of Fellows and the process for submitting nominations are on the AMS website (www .ametsoc.org/ams/index.cfm/about-ams/ams-awards-honors/awards/).
* The Lectureships for 2020 have already been awarded by the AMS Council. Nominations for the 2021 Lectureships are now open. 


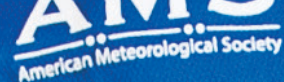

